Available online at

http://www.anpad.org.br/bar

BAR, Curitiba, v. 7, n. 1, art. 4,

pp. 59-78, Jan./Mar. 2010

\title{
The Role of Experiential Knowledge and Subsequent Investment Decisions on the Profitability of Japanese Companies in Brazil
}

\author{
Mário Henrique Ogasavara * \\ E-mail address: marioga@unifor.br \\ Programa de Pós-Graduação em Administração de Empresas/Universidade de Fortaleza \\ Fortaleza, CE, Brazil.
}

\begin{abstract}
This study attempts to empirically investigate how firms' experiential knowledge and the decision to invest sequentially in the host country are associated with the performance of their overseas subsidiaries. This research advances prior studies by adopting an objective performance measure based on the profitability ratio at the subsidiary level. Using a random-effect model of GLS regression applied to a panel data of Japanese firms established in Brazil, the results provide theoretical and practical implications showing that experiential knowledge is positively associated with subsidiary profitability. Local experiential knowledge can be acquired by managing subsidiaries for a long time in the host country, but also by increasing the number of investments in the local market. In practical terms, the subsidiary profitability ratio becomes higher when the parent firms have established more than five investments in the host country, although further investigation is needed to examine the direction of this relationship. Moreover, there is a significant association between subsidiary performance and the parent firms' experience in culturally similar markets to Brazil. The benefit of learning from international markets suggests that operating in countries with a similar culture transforms their experience into a competitive advantage.
\end{abstract}

Key words: experiential knowledge; subsequent FDI; performance; profitability.

Received 10 March 2009; received in revised form 03 July 2009.

Copyright (C) 2010 Brazilian Administration Review. All rights reserved, including rights for translation. Parts of this work may be quoted without prior knowledge on the condition that the source is identified.

\footnotetext{
* Corresponding author: Mário Henrique Ogasavara Avenida Washington Soares 1321, sala Q-03, Edson Queiroz, Fortaleza, CE, 60811-905, Brazil.
} 


\section{INTRODUCTION}

Rapid globalization of the world economy has brought intense changes in the way of conducting business. Firms face increasing international competition and try to take advantage of the growing opportunities offered by the international market. As a result, multinational companies have expanded the field of their business activities in different countries and cultures, which requires some capabilities to access and operate successfully in these markets. Usually, a multinational company faces uncertainty and risk, and is subject to the liability of foreignness (Hymer, 1976), which is associated with the cost of doing business in a different market from its home country. As the multinational enterprise increases know-how through experience by operating in international markets (Barkema, Bell, \& Pennings, 1996), building relations with customers and local suppliers, dealing with governmental agencies and recruiting local employees, its liability for foreignness should decline (Chang \& Rosenzweig, 1998) and perhaps even disappear (Zaheer, 2002).

Many scholars have observed the importance of experiential knowledge in the internationalization process (Eriksson, Johanson, Majkgard, \& Sharma, 1997; Johanson \& Vahlne, 1977). The term experiential knowledge refers to all types of knowledge that firms accumulate by being active in foreign markets, and implies the ability to search, analyze and act on international business issues in local markets (Blomstermo, Eriksson, Lindstrand, \& Sharma, 2004). Johanson and Vahlne (1977) also consider experiential knowledge as important for subsequent expansion of operations in a host country, as well as the increasing resource commitments in foreign markets. Since initial investments build network capabilities and the learning process (Song, 2002), prior experience in a host country tends to enhance the chance of selecting the same market for additional investments (Davidson, 1980).

Although previous research has found that experiential knowledge can reflect on higher performance, most studies have analyzed this approach on performance at the corporate level (Delios \& Beamish, 1999; Lu \& Beamish, 2001). There have been some studies based on performance at the subsidiary level; however, they are limited to the sample of investments in developed countries (Li, 1995) or Asian developing countries (Carlsson, Nordegren, \& Sjöholm, 2005; Makino \& Delios, 1996). Only a few empirical studies of subsidiary performance have paid attention to emerging economies outside the Asian region (Neupert \& Montoya, 2000; Ogasavara \& Hoshino, 2007). An emerging economy is a term coined by Antonie Van Agtmael during an investor conference in Thailand in 1981 to classify Third World countries that had a great growth potential but were also very volatile and posed significant risks (Agtmael, 2007).

Past studies have found that accumulation of experiential knowledge has led to enhanced performance while other streams of research emphasize the importance of experiential knowledge for the decision of subsequent investments in the same location (Chang \& Rosenzweig, 1998; Kogut \& Singh, 1988; Song, 2002). Surprisingly, no study has attempted to investigate whether or not firms that decided to invest sequentially in the host country, in fact, achieve a higher level of subsidiary profitability compared to firms that made only one investment.

This study distinguishes itself from previous research as it examines the effect of firms' international and local experiential knowledge and subsequent investment decision on subsidiary performance by investigating Japanese foreign direct investment in Brazil. More specifically, this paper analyzes whether or not subsidiaries of a parent firm with subsequent investment decisions in the local market achieve a higher level of profitability compared to subsidiaries of a first-time investor. Moreover, it attempts to investigate the impact of knowledge accumulation of prior international operations in other culturally similar countries on subsidiary performance. Attention to a single country permits the study to obtain the actual performance of firms. By examining a single host country (Brazil) and a single foreign direct investment [FDI] outflow country (Japan), it holds the country effects constant, which allows for greater theoretical and empirical attention to a firm's FDI performance (Hennart, 1991). Japanese multinational firms provide an appropriate sample for this study because they generally tend 
to follow a pattern of sequential entry by incrementally increasing their commitment to foreign markets through investments over a long period of time (Chang, 1995).

\section{LITERATURE REVIEW AND HYPOTHESES}

The internationalization process involves the accumulation of knowledge to compete effectively with host country firms in their own markets (Cohen \& Levinthal, 1990). This market knowledge is required to deal with culturally different employees, suppliers and customers. In addition, firms must adapt their production systems to the local infrastructure and customs to deal with governments and other institutions from this particular market. In the internationalization model, Johanson and Vahlne (1977) put forward the idea that relevant market knowledge can be divided into objective and experiential knowledge.

Objective knowledge is obtained and learned by researching the new market before making any investment decisions and comprises information of market size, customer purchasing power, laws, and regulations. This data can be collected through secondary sources such as newspaper articles, magazines, reports and the Internet as well as public and private databases. This knowledge is relatively easy to acquire and should not be significant for the firm's performance in the host country (Denis \& Depelteau, 1985).

With regard to experiential knowledge, Johanson and Vahlne (1977) consider two types: general and market-specific knowledge. General knowledge consists of marketing methods, rules and regulations related to purchases, sales, payments, employees and common characteristics of certain types of customers and suppliers without taking into account their geographical location. It is obtained by operating international business and can often be transferred from one country to another (Johanson \& Vahlne, 1990). Having longer international experience allows the company to better understand the complexity of cognitive, normative and regulatory domains in different environments and, consequently, gain more general knowledge. Hence, internationalization is a gradual process in which multinational firms accumulate experiential knowledge over time (Blomstermo et al., 2004).

Another way to gain experiential knowledge is related to the process of managing many subsidiaries in a number of countries (Huber, 1991), building a repertoire of knowledge and skills in dealing with different requirements from the environment (Zahra, Ireland, \& Hitt, 2000). Therefore, this study adopts the term firms' international experiential knowledge to define the general knowledge that a multinational company has acquired in terms of length of time and scope of operating international subsidiaries.

Previous research has shown a positive relationship between general knowledge and firm performance. In a study of corporate performance of Japanese companies, Delios and Beamish (1999) found that geographic scope (measured by the number of subsidiaries and countries invested abroad) is positively related to firm profitability. Lu and Beamish (2001) also found that greater levels of FDI are associated with higher performance when investigating a sample of Japanese small and medium-sized companies. However, these studies focused on performance at the corporate level rather than the subsidiary level. Therefore, it will be interesting to use subsidiary level data to test the effect of firms' international experiential knowledge on subsidiary performance. It is expected that as firms accumulate experiential knowledge over a period of time, increasing the scope of international investments by operating in different markets, this portfolio of knowledge can be transferred to its subunits and, consequently, this will reflect an increase in subsidiary performance. Thus, it is hypothesized that:

Hypothesis 1: The increase of international experiential knowledge (length of time and scope of overseas subsidiaries) is related to a higher subsidiary performance. 
Moreover, multinational firms can also learn from outside the local market, which allows organizations to transform their experience into a competitive advantage (Teece, Pisano, \& Shuen, 1997). Learning from external markets can be related to the function of the firm's prior level of related knowledge (Cohen \& Levinthal, 1990). Learning is cumulative, and the ability to learn is greatest when the object of learning is related to what is already known. The more knowledge a firm has about a market, the easier and faster it can gain knowledge about a related market (Carlsson et al., 2005). Pan and Li (1998) suggest that joint ventures in China tend to be relatively successful if the foreign partner has been exposed to Greater China. In this sense, the experience accumulated in countries that are more similar to the local market seems to be an important factor for lowering uncertainty and, as a result, enhancing subsidiary performance. Thus:

Hypothesis 2: The firms' international experiential knowledge in countries that have a more similar culture to the local market is associated with a higher subsidiary performance.

Market (country)-specific knowledge is related to knowledge of the specific country and its characteristics. It is critical to firms' internationalization (Penrose, 1959) and cannot be obtained as easily as objective knowledge because information tends to be complicated and tacit (Johanson \& Vahlne, 1977). Furthermore, this knowledge is very difficult to acquire through contracts (Hennart, 1988). Experiential market-specific knowledge can be learned only through learning-by-doing (Johanson \& Vahlne, 1977). Firms need to experience a particular market to establish the initial knowledge base and to understand and evaluate the context of the host country (Cohen \& Levinthal, 1990). When firms have operated for a long period of time in the local market, it allows multinational companies to have diversity interaction with workers, customers, suppliers and other local institutions (Zahra et al., 2000). In addition, it helps the firm to learn more about the specific market developing more capabilities (Chang, 1995) and increasing know-how of doing business in the host country (Luo \& Peng, 1999). On the one hand, the accumulation of knowledge in a particular country is timeconsuming. On the other hand, it helps the firm overcome initial concerns about dealing with international operations while reducing operational uncertainties and increasing performance (Makino \& Delios, 1996).

Additionally, firms can gain and increase market-specific knowledge by managing other subsidiaries in the same host country. A firm that accumulates prior knowledge in the market can be in an advantageous position to assimilate and exploit new knowledge (Cohen \& Levinthal, 1990). When firms operate a number of subunits in the same host country, they can gain advantage of greater scale economies by sharing facilities, workforce, know-how and other resources across subsidiaries (Song, 2002). Hence, a firm intensifies local knowledge by increasing social networks with suppliers, business and community leaders and government officials. This study considers the term firms' local experiential knowledge to define the country-specific knowledge that a firm has obtained in terms of length of time and scope of operating local subunits.

Carlson (1975) suggests that the more different the foreign environment is compared to the firm's current markets, the more difficult it is for the multinational company to gain market-specific knowledge. Firms usually have greater familiarity with business opportunities in their immediate surroundings rather than far away markets. Therefore, it takes a long time to gather and interpret market information from places that are at a high psychic distance from the firm's current markets. Due to the psychic distance and cultural and institutional differences between Japan and Brazil (Hofstede, 1980, 1991) ${ }^{(1)}$, and given that both countries are classified as independent from other cluster countries (Ronen \& Shenkar, 1985), the Japanese firms would have a great need to learn about local culture and business practices in Brazil. Consequently, increasing firms' local experiential knowledge would be crucial for Japanese subsidiaries to achieve greater profitability. Therefore, it is hypothesized that:

Hypothesis 3: The increase of local experiential knowledge (length of time and scope) is related to a higher subsidiary performance.

Kogut (1983) argues that when multinational firms invest in foreign markets the investment decision 
is not discrete, but should be perceived as a series of factors that decide the volume and direction of capital and resource flows among different markets. In this way, foreign direct investment has also been considered as a sequential process, where initial investments affect the nature and timing of additional investments. In the same way, Chang and Rosenzweig (1998) point out that many previous studies have considered FDI activity as a static decision-making process, assuming that the investment decision is independent of past FDI activities by the same firm. Johanson and Vahlne (1977) developed a model for the internationalization process considering international expansion as a series of step-by-step decisions. This means that after having a notion of familiarity with the host country, multinational firms would increase experience and knowledge of the specific environment and perceive less uncertainty. Thus, firms become more confident in their abilities and capabilities to correctly estimate risk and return, manage their operation effectively and, consequently, increase their investment commitments to the local market.

Past research has focused on the firm's motivation (Chang, 1995) and the entry decision of multinational companies (Chang \& Rosenzweig, 1998) that provide subsequent investment into a local market. However, given that prior experience in a particular location tends to increase the likelihood of selecting the same market for subsequent investments (Davidson, 1980; Kogut \& Singh, 1988; Song, 2002), and based on findings that accumulated experiential knowledge achieves greater profitability (Delios \& Beamish, 2001; Luo \& Peng, 1999), there remains the question of whether or not firms with subsequent investment decisions in the same host country will, in fact, enhance the profitability of their subsidiaries.

Multinational firms that decide to invest sequentially in a particular market would have more advantages related to the local experiential knowledge such as the network of the subsidiaries. In other words, a firm could achieve greater scale economies by sharing facilities, information and knowledge about local markets in relation to customers, suppliers, specific regulations and laws, and other resources across subsidiaries (Song, 2002). However, firms without subsequent FDI in the host country see few benefits of network information, because they are restricted to their own customers, suppliers and government institutions. Based on these assumptions it is hypothesized that:

Hypothesis 4: Firms that engage in subsequent investment in the local market achieve a higher level of subsidiary profitability than first-time investors.

\section{SAMPLE}

For this study, subsidiary level data were based on the extensive information of investment made by Japanese multinational firms in Brazil from 1998 to 2002, which were derived from two main data sources. First, the 2002 and 2004 editions of Anuário: Empresas Japonesas no Brasil - Burajiru Nikkeikigyo Nenkan (Yearbook: Japanese companies in Brazil), a yearbook published in Brazil since 1974. It is a bilingual edition published in Portuguese and Japanese. The 2002 and 2004 editions of this yearbook cover the end of the fiscal year from 1998 to 2002. Second, the 1999 to 2003 issues of Kaigai Shinshutsu Kigyou Souran: Kuni Betsu, Kaisha Betsu (Toyo Keizai Databank: Japanese Overseas Investments: by country and by company), a directory published annually in Japanese since 1970 by Toyo Keizai, Inc., which provides information on the FDI of listed companies on the Japan stock exchanges (Tokyo, Osaka and Nagoya), as well as by major unlisted Japanese firms. The initial dataset contains a list of 447 subsidiaries established by 286 Japanese firms in Brazil.

From each subsidiary, the major Japanese parent firm was listed and information obtained in both databases mentioned earlier. Additional parent company information was collected from the 1999 to 2003 editions of Nikkei Kaisha Nenkan: Jyoujyou Kaishaban (Nikkei Annual Corporation Report: Listed Companies) and Nikkei Soukan: Mijyoujyou Kaishaban (Nikkei Annual Corporation Report: Unlisted Companies). 
Where required, additional subsidiary information was gathered from various editions of Exame Melhores e Maiores (Exame Magazine - Biggest and Best), which supplies detailed data about the top 500 private companies in Brazil. This publication includes company balance sheets, reports, economic scenarios and market trends. In addition, it uses various issues of Valor 1000 (Value 1000), which provides financial information on the top 1,000 private companies in Brazil; and Infoinvest Análise de Empresas (Company Analysis), an electronic dataset available on the Internet which includes annual reports, balance sheets and information of 2,832 companies in Brazil.

The unit of analysis of this study is the subsidiary performance based on financial outcome measures between the periods 1998 and 2002. From the original sample of 447 subsidiaries, the sample was reduced to 119 cases. Due to incomplete data for all the independent variables used in this study, it resulted in a final count of 110 subsidiaries for the analysis. Based on a cross-sectional time series design, which means that each subsidiary contains information for five years (1998-2002), this study provides a total of 550 observations.

In order to investigate whether or not the reduced sample considered in this study is equal to the full sample, a standard $t$-test of non-response bias was conducted. The null hypothesis is that the averages of both samples are equals. Because the analysis of this study focused on a firm's experiential knowledge, a $t$-test on a parent firm with years of experience in the local market was performed. Although not reproduced in this paper, the results revealed no significant differences (i.e. the parent firm's experience in the host country) between subsidiaries in the reduced sample and subsidiaries in the full sample.

\section{DEPENDENT VARIABLE}

The subsidiary performance is the dependent variable adopted in the empirical analysis. Most studies of Japanese FDI performance had used the database published in Japanese by Toyo Keizai Inc. to obtain the information of subsidiary performance (Beamish, Delios, \& Lecraw, 1997; Beamish, Delios, \& Makino, 2001; Delios \& Beamish, 2001; Makino \& Delios, 1996; Nitsch, Beamish, \& Makino, 1995, 1996; Siripaisalpipat \& Hoshino, 2000; Woodcock, Beamish, \& Makino, 1994). This database provided information of a subjective measure of performance based on the managerial assessment of profitability on a scale of three levels: loss, breakeven and gain. Although prior studies have provided a number of contributions to studies of Japanese subsidiaries by adopting this subjective measure of performance, scholars have assumed the limitation of this measurement and argued that it represents only the information Japanese companies are willing to provide given their very private nature (Delios \& Beamish, 2001; Woodcock et al., 1994). There was an initial attempt to use this subjective measure of performance; however, when taking into account Japanese investments in Brazil, the number of subsidiaries that reported this subjective performance measure decreased year after year. At the end of fiscal year 2002, there were only 28 cases of subsidiaries with performance data. Given such a small sample, it became difficult to apply a quantitative analysis using statistical tools.

There is a need to consider other performance measurements. The use of an objective measure of subsidiary performance (i.e. profitability ratio) can provide a good contribution to the international business literature. First, it is well recognized that a profitability ratio at the subsidiary level is very difficult to collect (Brouthers, Brouthers, \& Werner, 1999; Woodcock et al., 1994), which puts some constraints on the investigation of subsidiary performance (Shaver, Mitchell, \& Yeung, 1997). If the subsidiary profitability ratio is available, it will provide a great opportunity to test whether or not it can be a good measure of performance.

Second, when prior studies adopted objective measures of performance, it should be noted that they applied performance measures at the corporate level rather than at the subsidiary level. For instance, Tallman and $\mathrm{Li}$ (1996) examined the relationship between the international diversity, product diversity and corporate performance of 192 large U.S. multinational firms. The dependent variable of their 
study was based on a return on sales (ROS) measure. Delios and Beamish (1999) investigated the relationship of geographical scope, product diversification and corporate performance of 399 Japanese manufacturing firms. They compiled three performance measures that presented a high degree of correlation: return on assets (ROA), return on equity (ROE), and return on sales (ROS).

Third, most studies have adopted subjective rather than objective measurement, based on the assumption that both performance measures are highly correlated (Geringer \& Hebert, 1991). However, their results could not include actual profit ratios as one of their objective measures because the data were not available. The assumption was based on interviews with the managers, which revealed that their assessment of success and whether the profitability of the venture was better than expected were positively and significantly correlated. Thus, this study provides a great opportunity to test whether or not the data based on a profitability ratio at a subsidiary level can be a good measure for performance. Finally, for the investigation on subsequent FDI, Li (1995) suggested the need for future research applying different measures of performance rather than firm survival. Hence, this study attempts to meet this need by applying an objective measure of subsidiary performance.

This research employed a profitability ratio as a dependent variable based on a return on sales $(\mathrm{ROS})^{(2)}$, defined as profit before tax divided by total sales. This profitability ratio was collected from a singular database of Japanese investments called Anuário: Empresas Japonesas no Brasil (Yearbook: Japanese companies in Brazil), which provided financial statements at the subsidiary level. When required, additional performance data were gathered from Exame Melhores e Maiores, Valor 1000, and InfoInvest Análise de Empresas databases.

\section{INDEPENDENT VARIABLES}

The independent variables used in this study refer to the firms' international experiential knowledge, firms' local experiential knowledge, subsequent investment and some control variables which are expected to have an impact on the performance of Japanese subsidiaries in Brazil.

\section{International Experiential Knowledge}

Length of time of international experiential knowledge [INT_LENGTH]. This variable measures the length of time of the parent firm's international experience by operating overseas subsidiaries. It is defined as the total number of years (in a logarithmic form) the parent firm had established international investment (i.e. a country other than Brazil) until the year of analysis. Since the distribution of length of time does not follow the normal distribution curve, the use of the natural logarithm is applied to smooth the values and bring them to the normal distribution.

. Scope of international experiential knowledge [INT_SCOPE]. This variable considers the parent firm's network of subsidiaries abroad. It is measured by the parent firm's total number of foreign subsidiaries, calculated as the number of overall subsidiaries that the parent firm established overseas minus one, which is the focal subsidiary. It is necessary to deduct one; otherwise the focal subsidiary would be counted in the variable which becomes redundant.

. International experiential knowledge of weighted average of cultural similarity with the local market [INT_CULT_SIMIL]. This variable is computed in three steps. First, it applies the composite index developed by Kogut and Singh $(1988)^{(3)}$, which many studies have subsequently used as a measure of cultural distance (Barkema et al., 1996; Padmanabhan \& Cho, 1996). Based on this composite index, it implies that a lower value of this index indicates low cultural distance of the $j$ th country to Brazil; conversely a higher value means high cultural distance. It is necessary to weight this composite index in order to obtain a high weight for countries with low cultural distance (high cultural similarity), and a low weight for countries with high cultural distance (low cultural 
similarity) from Brazil. Thus, the second step transforms the composite index into a weight $\left(\mathrm{WCS}_{\mathrm{j}}\right)$ by subtracting the cultural distance index from a constant value ${ }^{(4)}$. However, the new variable of cultural similarity $\left(\mathrm{WCS}_{\mathrm{j}}\right)$ needs some other adjustments ${ }^{(5)}$. Thus, the third step is to apply the weighted average of the cultural similarity index of different countries that the parent firm established subsidiaries ${ }^{(6)}$.

It is expected that the longer firm's international experience of operating in countries that share similar culture to the local market could reflect higher profitability. In this way, an interaction term [INT_LENGTH*INT_CULT_SIMIL] is considered in order to take into account both firms' international experiential knowledge in terms of length of time [INT_LENGTH] and in terms of experience in countries with similar cultures [INT_CULT_SIMIL].

\section{Local Experiential Knowledge}

Length of time of local experiential knowledge [LOC_LENGTH]. This is based on the parent firm's years of experience in the local market. It is computed as the logarithmic form of the total number of the firm's years of experience in the host country.

. Scope of local experiential knowledge [LOC_SCOPE]. This variable measures the parent firm's network of subsidiaries in the host country. It is defined as the number of subsidiaries the parent firm has established in the local market.

\section{Subsequent Investment}

Subsequent investment is defined as the establishment of a new subsidiary by the Japanese parent firm in Brazil, which may or may not be in the same line of business. It means that subsequent investment does not refer to an expansion of an existing subsidiary, but a creation of a new business operation in the same local market.

Scope of local experiential knowledge for subsidiaries of first-time entrants [1_INVEST]. This dummy variable measures the subsidiaries of first-time investors. A one is assigned to subsidiaries of a parent firm with only one investment in the local market, and zero otherwise. In other words, this dummy variable refers to subsidiaries of parent firm without subsequent FDI in the local market.

\section{- Scope of local experiential knowledge for subsidiaries of a parent firm with two to four investments [2-4_INVEST]. This dummy variable measures the subsidiaries of a parent firm with two to four investments in the local market. A one is assigned to subsidiaries of a parent firm with two to four investments, and zero otherwise.}

It should be noted that subsidiaries of parent firms with more than five investments in the local market is considered the reference measure in the regression analysis.

\section{Control Variables}

Assuming the existence of different performance levels across industries, there is a need to control for industry effects. Japanese companies have the feature of establishing mostly manufacturing operations abroad (Kogut \& Singh, 1988), which is consistent with the sample distribution of this study (56\% of cases are manufacturing subsidiaries). In this way, a dummy variable [INDUST] is considered, which gives a value of one for manufacturing firms and value of zero for nonmanufacturing firms.

The degree of control of the parent firm over its subsidiary also figures prominently (Luo \& Peng, 1999). According to Tallman and Shenkar (1994), the multinational company has greater influence over its wholly-owned subsidiaries than over joint ventures. Therefore, a dummy variable 
[D_CONTROL] is coded as one if the parent firm has full control over its subsidiary (wholly-owned subsidiary), and zero if the firm shares the control with a local partner (international joint ventures) $)^{(7)}$.

When examining the effect of firm diversification, prior research has shown that unrelated units are more likely to exit than subsidiaries operating in the same activity of the parent firm ( $\mathrm{Li}, 1995)$. Therefore, it is important to control for firm diversity by comparing the main line of business of the Japanese parent firm with the subsidiary's industry [RELATED], where related entries are coded as one, and unrelated entries are coded as zero.

The subsidiary age is considered to control the effects of operation length in the local market. However, when the length of time is considered in terms of operational years in the host country, this measure is highly correlated with the parent firm's years of operation in the local market [LOC_LENGTH]. Thus, a dummy variable [SUB_AGE] is assigned to control for this effect based on the mean and median of a subsidiary age (28 years) in the sample. Therefore, it is coded zero for subsidiaries with fewer than 27 years of operation (52 cases), and one for subsidiaries with more than 28 years of operation in the local market (58 cases).

It is also important to control for subsidiary size as greater organizational size may afford more investment and attention from the parent firm requiring a high performance level to sustain. The number of employees in the subsidiaries [SUB_SIZE] is adopted to control the subsidiary size. Due to the large range between minimum and maximum values, a logarithmic transformation is applied in order to smooth the values and bring them to the normal distribution. Next, the size of the parent company [PAR_SIZE] is controlled as large multinational companies tend to have more operations in international markets and financial resources compared to small firms. In this way, the information of the parent firm's total sales is used as a proxy for the size of the parent company. As applied in the previous control variable, a logarithmic transformation is considered due to the large range between the high and low amount of total sales.

For international experiential knowledge, it is necessary to control the decaying effect of international experience. Previous research has indicated that the benefit of experience to organizations may decay over time due to forgetting and antiquation of learning (Argote, Beckman, \& Epple, 1990). In order to control the possibility of the decaying effect of experience, a control variable is considered by using the coefficient of variation in firms' international experience [CV_INT_EXP]. The coefficient of variation is computed by dividing the standard deviation of international experience in year $t$ (i.e. 1998 to 2002) of the parent firm X by the mean of international experience in year $t$ of the parent firm X. By using the coefficient of variation, it is possible to estimate the variance of firms' international experience.

\section{EMPIRICAL ANALYSIS AND DISCUSSION}

This study intends to analyze the impact of firms' international and local experiential knowledge and subsequent investment decisions on the performance of subsidiaries. Before performing the statistical analysis, the correlation among the independent variables was checked in order to identify signs of multicollinearity. Due to a page limitation, the correlation matrix is not reported in this paper. A high correlation was found between the variables LOC_SCOPE with INT_SCOPE (0.899), thus the orthogonalization technique was applied in Model 3, using a modified Gram-Schmidt procedure (Cohen \& Cohen, 1983) that partials out the common variance creating transformed variables that are uncorrelated with one another. The order of variables determines the orthogonalization. In this case, LOC_SCOPE is the most important predictor for a subsidiary performance (ROS); thus, this variable is listed first followed by INT_SCOPE. After this transformation in these models, the variance inflation factor (VIF) was examined to determine the existence of multicollinearity under each model in Table 1. The results reveal that the VIF scores for each independent variable do not reach the critical 
point of 10 (Chatterjee \& Price, 1991), indicating that multicollinearity should not be a problem with these data.

In order to examine the impact of firms' international and local experiential knowledge on subsidiary performance, a random-effects model of generalized least squares with AR(1) disturbance was applied to cross-sectional time series data ${ }^{(8)}$. Performance of a subsidiary is explained by the following model:

Subsidiary Performance $=\mathrm{f}$ [Parent firm's international experiential knowledge, Parent firm's local experiential knowledge (Subsequent FDI decision)]

The model can be expressed as:

$$
y_{i t}=\alpha+x_{i t} \beta_{1}+v_{i}+\varepsilon_{i t} \quad i=1, \ldots, N ; \quad t=1, \ldots, T_{i}
$$

where $\varepsilon_{i t}=\rho \varepsilon_{i, t-1}+\eta_{i t}$ and where $|\rho|<1$ and $\eta_{i t}$ is independent and identically distributed (i.i.d) with mean 0 and variance $\sigma_{\eta}^{2}$.It is assumed $v_{i}$ to be realizations of an i.i.d. process with mean 0 and variance $\sigma_{\eta}^{2}$. Furthermore $v_{i}$ are assumed to be independent of both the $\varepsilon_{i t}$, and the covariates $x_{i t}$ (random-effects model).

Five different models with all control variables are tested and reported in Table 1. Model 3 considers all variables together; however, because the variables [INT_SCOPE] and [LOC_SCOPE] are highly correlated as mentioned earlier, the orthogonalization technique was applied using a modified GramSchmidt procedure in order to make them mathematically independent (Cohen \& Cohen, 1983).

Model 1 shows the impact of firms' international experiential knowledge on subsidiary performance. The coefficients of length of time of international experiential knowledge [INT_LENGTH] and the scope of international experiential knowledge [INT_SCOPE] are positively and significantly related to performance. This suggests that increasing the parent firm's international experience in terms of time and scope improves subsidiary performance, which is in accordance with prior research (Huber, 1991). For the variable that considers the cultural similarity between $j$ th countries and Brazil [INT_CULT_SIMIL], it is shown to be positively and significantly associated with performance. This implies that the parent firm's international experience in countries of similar culture to the focal market has an impact on a subsidiary's performance. This is connected with the firm's absorptive capacity, which is the ability to recognize the value of new, external information and to assimilate and apply it (Cohen \& Levinthal, 1990). Experience outside the local market is likely to be helpful if firms can select routines that are beneficial for transfer to the local market. The interaction term between length of time [INT_LENGTH] and the cultural similarity [INT_CULT_SIMIL] of international experiential knowledge [INT_LENGTH* INT_CULT_SIMIL] shows a negative but insignificant coefficient.

For control variables, both coefficients related to size [SUB_SIZE, PAR_SIZE] are statistically significant, but an interesting result was found. Both coefficients are negatively related to profitability, implying that subsidiary size [SUB_SIZE] matters for subsidiary performance. This means that smallsized subsidiaries achieve a higher level of profitability than large-sized firms. This negative relationship between subunit size and performance was found in a study of Luo and Peng (1999). They used a sample of subsidiaries operated in a developing country (China), and noted that size is only marginally important for sales growth, but irrelevant to other performance measures. Siripaisalpipat and Hoshino (1999) also found that a firm's size seems to be negatively associated with performance when investigating Japanese investment in a developing country (Thailand). They suggested that large-sized firms usually aim at maintaining stable and long term growth, thus being satisfied with moderate profit rates. In addition, the negative effect of the parent firm's size on subsidiary profitability can also be explained by the transfer pricing. Larger firms may be more likely to move taxable income from Brazilian subsidiaries. For other control variables [INDUST ${ }^{(9)}$, RELATED, 
D_CONTROL, SUB_AGE, CV_INT_EXP], it is found not to be statistically significant with subsidiary performance.

Model 2 considers the effect of firms' local experiential knowledge on subsidiary performance. As expected, the coefficients of length [LOC_LENGTH] and scope [LOC_SCOPE] of firms' local experiential knowledge are positively and statistically significant in relation to subsidiary performance, confirming the results presented by previous studies (Luo \& Peng, 1999; Song, 2002). These findings suggest that accumulation of firms' market-specific knowledge comprises an important force to enhance the profitability of its subsidiary. As a firm gains experience by operating its subunits for a long period of time in the local market, it helps to learn more about the host country and, consequently, it reduces operational uncertainty and enhances subsidiary performance. Furthermore, as the firm expands with more investments, increasing the network of subsidiaries into the same local market, a greater scale of economy is achieved by sharing facilities, personnel and other resources across subsidiaries (Song, 2002). It also leads to improvement of the profitability of its subunits. In other words, the firm's subsequent investment decision allows for the efficient transfer of knowledge and experience within subsidiaries and, consequently, it reflects on achieving a higher level of subsidiary profitability. For the control variables, the findings showed the same results as reported in Model 1.

Model 3 tests the impact of both firms' international and local experiential knowledge on subsidiary performance. The results show that firms' international experiential knowledge [INT_LENGTH and INT_CULT_SIMIL] and local experiential knowledge [LOC_SCOPE and LOC_LENGTH] are positively and significantly associated with subsidiary performance. This implies that the firms' international experiential knowledge in terms of length of time operating in international markets and the accumulation of firms' local experiential knowledge in terms of length of time of operation and scope of subsidiaries in the local market help firms to increase the profitability of its subsidiaries. In addition, the international experience in countries that are more culturally similar to the local market has a positive effect on the subsidiary performance. The coefficient of international experiential knowledge in terms of scope of subsidiaries [INT_SCOPE] becomes statistically insignificant when considered with all variables in the analysis. The interaction term [INT_LENGTH*INT_CULT_SIMIL] has a negative but insignificant coefficient. For the control variables, the findings showed the same results as reported in Model 1.

In Models 1, 3 and 5, the decaying effects of international experience are controlled with the coefficient of the variation of firms' international experience [CV_INT_EXP]. Another way of capturing the decaying effects can be obtained by computing a discount factor in the variable $\left[{ }_{I N T_{-} L E N G T H}\right]$. Although not reproduced in this paper, but available upon request, three discount factors Discount are considered in the analysis as suggested by Ingram and Baum (1997). First, the discount factor is equal to the square root of the age of the first international experience, which assumes that depreciation of the experience is initially slower than linear, and slows further with time. Second, the discount factor is equal to the age of the first international experience, which assumes a linear depreciation in the value of prior experience. Third, the discount factor is equal to the age of the first international experience squared, which assumes that the value of past experience depreciates more rapidly than linear at first, and then accelerates further with time. The results reveal similar findings as shown in Table 1. This implies that the length of time of international experience $\left[\frac{\text { INT_LENGTH }_{\text {Discount }}}{\text { D }}\right.$ is positively and significantly associated with performance. But the benefit of experience to organizations may decay over time due to forgetting of knowledge gained from experience in the past and possible antiquation of learning due to environmental change (Argote et al., 1990).

In order to improve the analysis by considering at the same time in the regression model the subsequent FDI and the scope of firms' local experiential knowledge, two dummy variables are applied: [1_INVEST] refers to subsidiaries of first-time investors; and [2-4_INVEST] considers subsidiaries of a parent firm with two to four investments in the local market. Both dummy variables are compared to the subsidiaries of a parent firm with more than five investments in the host country, which is the reference measure. Because these dummy variables are constructed based on 
[LOC_SCOPE], both dummy variables are used instead of [LOC_SCOPE]. The results are depicted in Table 1 with Models 4 and 5.

Model 4 tests only the effect of firms' local experiential knowledge on subsidiary performance. In terms of subsequent FDI, the result shows that the coefficient of [1_INVEST] is negative and statistically significant. The negative sign means that subsidiaries of first-time investors (i.e. subsidiaries with no subsequent FDI) achieve lower performance than subsidiaries of a parent firm with more than five investments in the local market (i.e. subsidiaries with subsequent FDI). Concerning scope of subsidiaries in the local market, the outcome shows a negative and significant coefficient for subsidiaries of a parent firm with two to four investments [2-4_INVEST]. It suggests that increasing the number of subsidiaries in the local market reflects a higher level of profitability. The coefficient [LOC_LENGTH] is positive and significant, implying that a longer operation in the host country is an important factor when it comes to achieving a higher level of subsidiary performance. 
Table 1

Random Effects GLS Regression with AR(1) disturbances for Subsidiary Performance (Full Sample, Dependent Variable = ROS)

\begin{tabular}{|c|c|c|c|c|c|c|}
\hline \multicolumn{2}{|c|}{ VARIABLES } & MODEL 1 & MODEL 2 & MODEL 3 & MODEL 4 & MODEL 5 \\
\hline \multicolumn{2}{|l|}{ Constant } & $0.417^{* * *}(2.62)$ & $0.255^{*}(1.71)$ & $0.280^{*}(1.67)$ & $0.343^{* *}(1.97)$ & $0.400^{* *}(2.15)$ \\
\hline \multicolumn{7}{|l|}{ International Experiential Knowledge } \\
\hline INT_LENGTH & $\begin{array}{l}\text { Length of time of firms' international } \\
\text { experiential knowledge }\end{array}$ & $0.029^{*}(1.87)$ & - & $0.028^{*}(1.88)$ & -- & $0.026^{*}(1.81)$ \\
\hline INT_SCOPE ${ }^{\mathrm{o}}$ & $\begin{array}{l}\text { Scope of firms' international } \\
\text { experiential knowledge }\end{array}$ & $0.0003^{* *}(2.45)$ & - & $0.017(1.16)$ & -- & $0.023(1.44)$ \\
\hline INT_CULT_SIMIL & $\begin{array}{l}\text { Weighted average of cultural } \\
\text { similarity }\end{array}$ & $0.122^{* *}(1.96)$ & - & $0.200^{* *}(2.08)$ & -- & $0.156^{*}(1.65)$ \\
\hline INT_LENGTH*INT_CULT_SIMIL & Interaction term & $-0.024(1.63)$ & - & $-0.034(1.55)$ & -- & $-0.026(1.45)$ \\
\hline \multicolumn{7}{|l|}{ Local Experiential Knowledge } \\
\hline LOC_LENGTH & $\begin{array}{l}\text { Length of time of firms' local } \\
\text { experiential knowledge }\end{array}$ & -- & $0.073^{* * *}(2.82)$ & $0.088^{* * *}(3.25)$ & $0.068^{* * *}(2.54)$ & $0.077^{* * *}(2.80)$ \\
\hline $\mathrm{LOC}_{-} \mathrm{SCOPE}^{\mathrm{o}}$ & $\begin{array}{l}\text { Scope of firms' local experiential } \\
\text { knowledge }\end{array}$ & -- & $0.009^{* *}(2.44)$ & $0.060^{* *}(2.85)$ & -- & -- \\
\hline 1_INVEST ${ }^{\#}$ & $\begin{array}{l}\text { Subsidiary of a firm with only } 1 \\
\text { investment in the local market }\end{array}$ & -- & -- & -- & $-0.092^{* *}(2.02)$ & $-0.129^{* *}(2.48)$ \\
\hline 2-4_INVEST ${ }^{\#}$ & $\begin{array}{l}\text { Subsidiary of a firm with } 2 \text { to } 4 \\
\text { investments in the local market }\end{array}$ & -- & -- & -- & $-0.084^{* *}(2.06)$ & $-0.098^{* *}(2.33)$ \\
\hline
\end{tabular}


Table 1 (continued)

\begin{tabular}{|c|c|c|c|c|c|c|}
\hline \multicolumn{2}{|c|}{ VARIABLES } & MODEL 1 & MODEL 2 & MODEL 3 & MODEL 4 & MODEL 5 \\
\hline \multicolumn{7}{|l|}{$\underline{\text { Control Variables }}$} \\
\hline INDUST & Industry (1=Manufacturing) & $-0.017(0.54)$ & $-0.003(0.12)$ & $-0.010(0.32)$ & $0.006(0.19)$ & $-0.002(0.06)$ \\
\hline RELATED & Relatedness (1=Related Industry) & $0.044(0.92)$ & $0.029(0.65)$ & $0.031(0.67)$ & $0.011(0.26)$ & $0.015(0.34)$ \\
\hline CONTROL & Degree of Control (1=WOS) & $-0.060(1.61)$ & $-0.019(0.59)$ & $-0.038(1.11)$ & $-0.018(0.56)$ & $-0.039(1.13)$ \\
\hline SUB_AGE & Subsidiary Age & $-0.006(0.31)$ & $-0.019(1.00)$ & $-0.024(1.21)$ & $-0.018(0.94)$ & $-0.023(1.16)$ \\
\hline SUB_SIZE & Subsidiary Size & $-0.044^{* * *}(5.30)$ & $-0.045^{* * *}(5.70)$ & $-0.049^{* * *}(5.67)$ & $-0.044^{* * *}(5.50)$ & $-0.045^{* * *}(5.52)$ \\
\hline PAR_SIZE & Parent Size & $-0.016^{*}(1.67)$ & $-0.018^{* *}(2.13)$ & $-0.023^{* * *}(2.40)$ & $-0.015^{*}(1.87)$ & $-0.024^{* *}(2.40)$ \\
\hline CV_INT_EXP & $\begin{array}{l}\text { Coefficient variation of firms' } \\
\text { intern. experience }\end{array}$ & $-0.019(0.53)$ & -- & $-0.016(0.45)$ & -- & $-0.011(0.32)$ \\
\hline Number of Observations & & 550 & 550 & 550 & 550 & 550 \\
\hline Number of firms (\# observation/firm) & & $110(5)$ & $110(5)$ & $110(5)$ & $110(5)$ & $110(5)$ \\
\hline Wald chi-square (d.f.) & & $48.75(12)$ & $56.48(9)$ & $65.96(14)$ & $54.95(10)$ & $63.82(15)$ \\
\hline Overall R ${ }^{2}$ (Model Significant) & & $0.2209(0.000)$ & $0.2479(0.000)$ & $0.2723(0.000)$ & $0.2448(0.000)$ & $0.2684(0.000)$ \\
\hline
\end{tabular}

Notes: $z$-value in parentheses; significant at the $* 10 \%$ level; $* * 5 \%$ level; $* * * 1 \%$ level. ${ }^{\circ}$ Indicates that in Model 3 highly correlated variables (INT_SCOPE and LOC_SOCPE) have been orthogonalized. In this case, LOC_SCOPE is listed first to determine the orthogonalization, because it is the most important predictor for performance. ${ }^{\#}$ The reference measure is the subsidiary of a firm with more than five investments in the local market. Model 1: effects of international experiential knowledge and control variables; Model 2 and 4: effects of local experiential knowledge and control variables; Model 3 and 5: effects of both international and local experiential knowledge and control variables. 
In Model 5, both coefficients [1_INVEST] and [2-4_INVEST] are negative and statistically significant, which means that subsidiaries of a parent firm with more investments in the local market (i.e. more than five investments), and consequently with more market-specific knowledge by operating many subsidiaries in the same focal market, are associated with a high level of subsidiary profitability. Most importantly, it shows that subsidiaries of first-time investors achieve lower levels of profitability than subsidiaries of firms with subsequent FDI decisions in the host country. As in Model 4, [LOC_LENGTH] shows a positive and significant association with subsidiary profitability. With regard to firms' international experiential knowledge, the parent firm's experience accumulated by operating for a long time in international markets [INT_LENGTH] and the international experience in countries with more cultural similarity to the local market [INT_CULT_SIMIL] are important factors for subsidiaries in improving their profitability level. The coefficient of scope of overseas subsidiaries [INT_SCOPE] is positive, but insignificant.

Although not included in this paper due to page limitations, some statistical tests were performed in order to compare subsidiary performance differences between firms with subsequent investment decision and first-time investors (no subsequent FDI). The results showed a significant mean difference between both groups $(\mathrm{p}<0.005)$. This suggests that subsidiaries of firms with subsequent investments ( 345 cases, ROS mean $=0.0743$ ) obtained a higher level of profitability than subsidiaries of first-time investors (205 cases, ROS mean $=0.0259)$. Furthermore, in order to test whether or not the increasing number of investments in the same local market, in fact, affects subsidiary profitability, the group of firms with subsequent investments was divided in two sub-groups based on median values of the number of subunits in the host country. Hence, one group is formed by subsidiaries of firms with two to four investments (35 subsidiaries, 175 observations) and other sub-groups with more than five investments in the host country (34 subsidiaries, 170 observations). Subsidiaries of firms with more than five investments showed a higher level of profitability (ROS mean $=0.1334)$ than firms with two to four investments $($ ROS mean $=0.0269)$ and first-time investors $($ ROS mean $=$ $0.0259)$. The difference in mean between groups (ANOVA) shows a significant result ( $<<0.001)$. Moreover, when the performance of firms with more than five investments is compared to other subgroups by applying post hoc test, the difference in mean is also statistically significant. Compared to firms with two to four investments and firms with no subsequent investment, this is significant at the 0.001 level. Although there is no significant performance difference between firms with two to four investments and first-time investors, the results revealed a higher level of subsidiary profitability for the firms with subsequent investment decision.

Therefore, Hypothesis 1 is supported by Model 1, while partially supported by Models 3 and 5; Hypothesis 2 is supported by Models 1, 3, and 5; Hypothesis 3 is confirmed by Models 2, 3, 4, and 5; Hypothesis 4 is supported by Models 4 and 5 .

\section{LIMITATIONS}

The findings presented in this study have to be considered within the context of some limitations in conjunction with the discussion of further research. First, the analysis of this paper focused on the outward FDI of one country (Japan) in one location (Brazil) which provides both strengths and weaknesses. As mentioned earlier, on the one hand it holds the country effects constant, which allows for greater theoretical and empirical attention to firms' FDI performance. On the other hand, some of the findings may be exclusive to the case of Japanese firms or to the Brazilian market. Future research should be undertaken to extend the sample to non-Japanese parents operating in other developing countries in order to investigate whether the finding of this study can be generalized. However, it should be noted that the financial performance data of foreign subsidiaries in many emerging economies is very hard to obtain. 
Second, the profitability measures used in this study (ROS) are merely an explicit measure of performance. In some cases, a firm accepts moderate profit rates for some strategic reasons such as market share orientation, transferring pricing and long term growth. A future study should consider a multidimensional construction of performance measurement, including not only financial measures but also covering market and strategic criteria.

Finally, this study has conducted the analyses based on performance data derived from archival sources. Hence, it is generally difficult to affirm that the results imply causality. Although the findings suggest a positive relationship between the subsidiary performance and subsequent FDI, and the causality test ${ }^{(10)}$ suggests that the relationship could be reversed, in fact, the database does not give precise information as to whether or not the subsequent investments lead to a high level of profitability or the high level of profitability leads to additional FDI. Future research should cover this limitation by collecting its own data based on face-to-face interviews with top managers of those parent firms or subsidiaries in order to confirm the findings obtained in the empirical results, particularly examining the reasons behind the higher profitability level achieved by subsidiaries of parent firms with more than five investments in the local market.

\section{CONCLUSION}

This study provides some implications and contributions to the international business literature by analyzing the impact of firms' experiential knowledge and subsequent investment decisions on the profitability of Japanese subsidiaries established in Brazil.

First, the accumulation of a firm's experiential knowledge has a great impact on the performance of its subunits. According to the findings, both the international and local experiential knowledge of firms are positively associated with subsidiary profitability. This implies that when firms are investing in a foreign market, their experiential knowledge accumulated by managing international operations and its network of foreign subsidiaries in different markets reveals an important effect on increasing the profitability level of a multinational firm's subsidiary. A longer experience gained by operating international business allows firms to better understand the complexity of cognitive, normative and regulatory domains in different markets and, consequently, gain more knowledge. However, it should be noted that the advantage to organizations of accumulating international experience may decay over time as shown by the findings when applying for a discount factor in the variable of international experience. Furthermore, firms also gain knowledge by managing a number of affiliates in a variety of countries; in other words, increasing the scope of international subsidiaries in different countries.

Second, this study suggests that investing firms may need additional knowledge and experience to operate successfully in culturally dissimilar countries. The large geographical and cultural distance between Brazil and Japan is well known. Brazil has also experienced a number of changes in its political and institutional environment. In this sense, the accumulation of firms' local experiential knowledge provides a context for interpreting the business market, increasing knowledge of clients, suppliers, competitors, government, institutional framework, rules, norms and values. This allows the firm to perceive business opportunities, increasing know-how of managing operations in the host country, reducing uncertainty and, consequently, enhancing subsidiary profitability.

Third, the findings suggest that firms can acquire local experiential knowledge not only by managing subsidiaries for a long time in the local market, but also by increasing the number of investments in the same location; in other words, making subsequent FDI in the host country. The empirical tests using panel data of profitability measured over a five-year period of Japanese investments in Brazil. Credible evidence suggests that subsidiaries of parent firms with subsequent FDI in the same host country are more profitable compared to the subsidiaries of first-time investment firms. Increasing the firm's network of subunits in the target country allows the firm to have greater scale economies by sharing facilities, information, personnel and other resources across subsidiaries. Thus, the findings 
The Role of Experiential Knowledge and Subsequent Investment Decisions on the Profitability of Japanese Companies in Brazil

demonstrate that subsequent FDI in the same host country is an effective strategy for improving the profitability level of multinational firms' subsidiaries in an emerging country.

Fourth, this study reveals that the knowledge obtained through the firm's experience from outside markets offers some advantages that can reflect on subsidiary performance. The benefit of learning from external markets pointed out the importance of having experience in countries with similar culture to the local market. The results make evident significant associations between subsidiary performance and the parent firms' experience in markets that are culturally similar to Brazil. This implies that firms can learn from outside the local market and transform their experience into a competitive advantage.

Finally, the findings presented in this study show clear evidence of the positive association between firms' international and local experiential knowledge and subsequent FDI with the profitability level of multinational firms' subsidiaries.

\section{NOTES}

1 According to Hofstede, the following dimensions of cultural scales (Brazil, Japan) are: power distance (69, 54), individualism $(38,46)$, uncertainty avoidance $(76,92)$, masculinity $(49,95)$, and long-term orientation $(65,80)$.

${ }^{2}$ In addition to ROS, it was also tested using another financial performance measure: return of equity (ROE $=$ Profit before tax divided by Shareholder's equity). Both results are similar and there is a high correlation between ROS and ROE. However, when considering ROE as a performance measure, the sample decreases to less than 100 cases. Another measure of performance, ROA (return on assets: profit before tax divided by total assets) is considered. However, due to the existence of many missing values for this dependent variable in the sample (only 80 cases have ROA data) this measure could not be considered for analysis. Hence, it is worth showing only the outcomes obtained by ROS measures.

${ }^{3}$ The composite index developed by Kogut and Singh (1988) is represented algebraically as: $C D_{j}=\sum_{I-1}^{4}\left\{\left(I_{i j}-I_{i b}\right)^{2} / V_{i}\right\} / 4$

where $C D_{j}$ is the cultural difference of the $j$ th country from Brazil, $I_{i j}$ represents the index of the $i$ th cultural dimension and the $j$ th country, $b$ stands for Brazil and $V_{i}$ is the variance of the index of the $i$ th dimension.

${ }^{4}$ It is applied to the equation $W C S_{j}=$ Constant Value $-C D_{j}$. The constant value is considered as 4 in order to have all the calculated values of weight higher than zero (the highest index of cultural distance is $\mathrm{CD}_{\text {Denmark }}=3.8845$ ).

${ }^{5}$ It is because most of the Japanese parent firms had international experience in many different countries. If the parent company had international experience in only one country other than Brazil, the value of cultural similarity is the value of $W C S_{j}$ of this $j$ th country with Brazil. But when the parent firm established subsidiaries in many different countries, the measure of cultural similarity is calculated considering the weighted average, which means that it takes into account the proportional relevance of each cultural similarity index $\left(W C S_{j}\right)$, rather than treating each cultural similarity index equally.

${ }^{6}$ The equation is computed as: ${ }_{W A C S}=\frac{\sum_{i=1}^{n} I N T_{-} L E N G T H_{i j} \times W C S_{i j}}{\sum^{n} I N T_{-} L E N G T H_{j}}$ where $W A C S_{j}$ is the weighted average of cultural similarity,

$I N T \_L E N G T H_{i j}$ is the international experiential knowledge accumulated in country $j$ th, $W C S_{i j}$ is the cultural similarity of country $i$ th to Brazil.

${ }^{7}$ The following classification was considered for subsidiary equity: a) Wholly-owned subsidiary - Japanese parent firm(s) holds at least $95 \%$ of the subsidiary equity; b) International Joint-Venture - formed between Japanese partner(s) and local partner(s). A single Japanese parent firm holds at least $10 \%$ and less than $95 \%$ of the subsidiary equity.

${ }^{8}$ The Hausman specification test is applied to examine whether or not the fixed or random effects model should be used. The null hypothesis tests whether or not the coefficients estimated by the efficient random effects estimator are the same as the ones estimated by the consistent fixed effects estimator. An insignificant $p$-value (Prob $>$ chi2 $=0.4603$ ) was found, which means that the random effects model may be more powerful and parsimonious. The Wooldridge test (Wooldridge, J. M. (2002). Econometric analysis of cross section and panel data. Cambridge: MIT Press.) was performed for the autocorrelation test in panel data, where the null hypothesis means that there is no first-order autocorrelation. A significant p-value (Prob $>\mathrm{F}=0.0064)$ was found, which indicates the presence of serial correlation. Hence, in order to account for first serial correlation, the random-effects model with AR(1) disturbances was considered.

${ }^{9}$ Another classification was considered for the control variable [INDUST] considering three industry sectors: primary 
industry (extractive and mineral resources), secondary industry (manufacturing), and tertiary industry (commerce and services). Although in the sample the tertiary sector $\left(\mu_{t}=0.1282, n=37\right)$ showed a higher profitability level compared to the primary sector $\left(\mu_{p}=-0.0167, n=11\right)$ and the secondary sector $\left(\mu_{s}=0.0262, n=62\right)$, the findings showed no statistically significant differences when considering this new industry taxonomy with other independent variables. Therefore, the original classification of industry sector (i.e. manufacturing and non-manufacturing) was applied in the analysis.

${ }^{10}$ In order to test whether or not past performance does not cause sequential investment, the causality test was performed. Testing causality, in the Granger sense (Granger, C. W. J. (1969). Investigating causal relations by econometric model and cross-spectral methods. Ecnonometrica, 37(3), 424-438.), involves using the $F$-test to test whether lagged information on a variable ROS (subsidiary performance) provides any statistically significant information about a variable of LOC_SCOPE (sequential investment) in the presence of lagged LOC_SCOPE. Thus, ROS was regressed against the lags ( $t$-1) of ROS and the lags $(t-1)$ of LOC_SCOPE by ordinary least squares (OLS), in which the null hypothesis is that ROS does not cause sequential investment. Conducting an $F$-test of the null hypothesis, the results show that $F(1,437)=8.05$ with p-value 0.0048 , then the null hypothesis can be rejected. This result suggests that past subsidiary performance has an influence on sequential investment; in other words, while the findings of this study indicate that sequential FDI leads to higher performance, the relationship between performance and sequential investment can be reversed

\section{REFERENCES}

Agtmael, A. V. (2007). The emerging markets century: how a new breed of world-class companies is overtaking the world. New York: Free Press.

Argote, L., Beckman, S. L., \& Epple, D. (1990). The persistence and transfer learning in industrial settings. Management Science, 36(2), 140-154.

Barkema, H. G., Bell, J., \& Pennings, J. (1996). Foreign entry, cultural barriers, and learning. Strategic Management Journal, 17(2), 151-166.

Beamish, P. W., Delios, A., \& Lecraw, D. J. (1997). Japanese multinationals in the global economy. Cheltenhan: Edward Elgar.

Beamish, P. W., Delios, A., \& Makino, S. (2001). Japanese subsidiaries in the new global economy. Cheltenhan: Edward Elgar.

Blomstermo, A., Eriksson, K., Lindstrand, A., \& Sharma, D. D. (2004). The perceived usefulness of network experiential knowledge in the internationalizing firm. Journal of International Management, 10(3), 355-373.

Brouthers, L., Brouthers, K., \& Werner, S. (1999). Is Dunning's eclectic framework descriptive or normative? Journal of International Business Studies, 30(4), 831-844.

Carlson, S. (1975). How foreign is foreign trade? A problem in international business research. Uppsala: Uppsala University Press.

Carlsson, J., Nordegren, A., \& Sjöholm, F. (2005). International experience and the performance of Scandinavian firms in China. International Business Review, 14(1), 21-40.

Chang, S. J. (1995). International expansion strategy of Japanese firms: capability building through sequential entry. Academy of Management Journal, 38(2), 383-407.

Chang, S. J., \& Rosenzweig, P. M. (1998). Industry and regional patterns in sequential foreign market entry. Journal of Management Studies, 35(6), 797-822.

Chatterjee, S., \& Price, B. (1991). Regression analysis by example. New York: John Wiley \& Sons, Inc.

Cohen, J., \& Cohen, P. (1983). Applied multiple regression - Correlation analysis for the behavioral sciences. Hillsdale: Lawrence Erlbaum. 
Cohen, W. M., \& Levinthal, D. A. (1990). Absorptive capacity: a new perspective on learning and innovation. Administrative Science Quarterly, 35(1), 128-152.

Davidson, W. (1980). The location of foreign direct investment activity: country characteristics and experience effects. Journal of International Business Studies, 11(2), 9-22.

Delios, A., \& Beamish, P. W. (1999). Geographic scope, product diversification, and the corporate performance of Japanese firms. Strategic Management Journal, 20(8), 711-727.

Delios, A., \& Beamish, P. W. (2001). Survival and profitability: the roles of experience and intangible assets in foreign subsidiary performance. Academy of Management Journal, 44(5), 1028-1038.

Denis, J. E., \& Depelteau, D. (1985). Market knowledge, diversification an export expansion. Journal of International Business Studies, 16(3), 77-89.

Eriksson, K., Johanson, J., Majkgard, A., \& Sharma, D. D. (1997). Experiential knowledge and cost in the internationalization process. Journal of International Business Studies, 28(2), 337-360.

Geringer, J. M., \& Hebert, L. (1991). Measuring performance of international joint venture. Journal of International Business Studies, 22(2), 249-263.

Hennart, J. F. (1988). A transaction costs theory of equity joint ventures. Strategic Management Journal, 9(4), 361-74.

Hennart, J. F. (1991). The transaction cost theory of joint ventures: an empirical study of Japanese subsidiaries in the United States. Management Science, 37(4), 483-497.

Hofstede, G. (1980). Culture's consequences: international differences in work related values. Beverly Hills: Sage.

Hofstede, G. (1991). Cultures and organizations: software of the Mind. New York: McGraw-Hill.

Huber, G. P. (1991). Organizational learning: the contributing process and the literatures. Organization Science, 2(1), 88-115.

Hymer, S. H. (1976). The international operations of national firms: a study of direct investment. Cambridge: MIT Press.

Ingram, P., \& Baum, J. A. C. (1997). Chain affiliation and the failure of Manhattan hotels, 1898-1980. Administrative Science Quarterly, 42(1), 68-102.

Johanson, J., \& Vahlne, J. E. (1977). The internationalization process of the firm: a model of knowledge development and increasing foreign market commitments. Journal of International Business Studies, 8(1), 23-32.

Johanson, J., \& Vahlne, J. E. (1990). The mechanism of internationalisation. International Marketing Review, 7(4), 11-24.

Kogut, B. (1983). Foreign direct investment as a sequential process. In C. P. Kindleberger \& D. Audretsch (Orgs.). Multinational corporations in the 1980s. Cambridge: MIT Press.

Kogut, B., \& Singh, H. (1988). The effect of national culture on the choice of entry mode. Journal of International Business Studies, 19(3), 411-432.

Li, J. (1995). Foreign entry and survival: effects of strategic choices on performance in international markets. Strategic Management Journal, 16(5), 333-351.

Lu, J., \& Beamish, P. W. (2001). The internationalization and performance of SMEs. Strategic Management Journal, 22(6/7), 565-586. 
Luo, Y., \& Peng, M. W. (1999). Learning to compete in a transition economy: experience, environment, and performance. Journal of International Business Studies, 30(2), 269-296.

Makino, S., \& Delios, A. (1996). Local knowledge transfer and performance: implications for alliance formation in Asia. Journal of International Business Studies, 27(5), 905-927.

Neupert, K., \& Montoya, R. (2000). Characteristics and performance of Japanese foreign direct investment in Latin America. International Journal of Public Administration, 23(5/8), 1269-1283.

Nitsch, D., Beamish, P. W., \& Makino, S. (1995). Characteristics and performance of Japanese foreign investment in Europe. European Management Journal, 13(3), 276-285.

Nitsch, D., Beamish, P. W., \& Makino, S. (1996). Entry mode and performance of Japanese FDI en Western Europe. Management International Review, 36(1), 27-43.

Ogasavara, M. H., \& Hoshino, Y. (2007). The impact of ownership, internalization, and entry mode on Japanese subsidiaries' performance in Brazil. Japan and the World Economy, 19(1), 1-25.

Padmanabhan, P., \& Cho, K. R. (1996). Ownership strategy for a foreign affiliate: an empirical investigation of Japanese firms. Management International Review, 36(1), 45-65.

Pan, Y., \& Li, X. (1998). Alliance of foreign firms in equity joint-ventures in China. International Business Review, 7(4), 329-350.

Penrose, E. (1959). The theory of the growth of the firm. Oxford: Basil Blackwell.

Ronen, S., \& Shenkar, O. (1985). Clustering countries on attitudinal dimensions: a review and synthesis. Academy of Management Review, 10(3), 435-454.

Shaver, J. M., Mitchell, W., \& Yeung, B. (1997). The effect of own-firm and other-firm experience on foreign direct investment survival in the United States, 1987-92. Strategic Management Journal, 18(10), 811-824.

Siripaisalpipat, P., \& Hoshino, Y. (1999). Performance of Japanese overseas subsidiaries: the effects of entry mode and ownership advantages. Japanese Journal of Administrative Science, 13(1), 19-32.

Song, J. (2002). Firm capabilities and technology ladders: sequential foreign direct investment of Japanese electronics firms in East Asia. Strategic Management Journal, 23(3), 191-210.

Tallman, S., \& Li, J. T. (1996). Effects of international diversity and product diversity on the performance of multinational firms. Academy of Management Journal, 39(1), 179-196.

Tallman, S. B., \& Shenkar, O. (1994). A managerial decision model of international cooperative venture formation. Journal of International Business Studies, 25(1), 91-113.

Teece, D. J., Pisano, G., \& Shuen, A. (1997). Dynamic capabilities and strategic management. Strategic Management Journal, 18(7), 509-533.

Woodcock, C. P., Beamish, P. W., \& Makino, S. (1994). Ownership-based entry mode strategies and international performance. Journal of International Business Studies, 25(2), 253-273.

Zaheer, S. (2002). The liability of foreignness, redux: a commentary. Journal of International Management, 8(3), 351-358.

Zahra, S. A., Ireland, R. D., \& Hitt, M. A. (2000). International expansion by new venture firms: international diversify, mode of market entry, technological learning, and performance. Academy of Management Journal, 43(5), 925-950. 